ISSN 2073-4344

www.mdpi.com/journal/catalysts

Article

\title{
Microbial Stereoselective One-Step Conversion of Diols to Chiral Lactones in Yeast Cultures
}

Filip Boratyński *, Ewa Szczepańska, Jakub Pannek and Teresa Olejniczak

Department of Chemistry, Wroclaw University of Environmental and Life Sciences, Norwida 25, Wrocław 50-375, Poland; E-Mails: ewaszczepanska@onet.eu (E.S.); jpannek@wp.pl (J.P.); teresa.olejniczak@up.wroc.pl (T.O.)

* Author to whom correspondence should be addressed; E-Mail: filip.boratynski@up.wroc.pl; Tel.: +48-71-3205-257; Fax: +48-71-3284-124.

Academic Editor: Keith Hohn

Received: 5 November 2015 / Accepted: 30 November 2015 / Published: 8 December 2015

\begin{abstract}
It has been shown that whole cells of different strains of yeast catalyze stereoselective oxidation of meso diols to the corresponding chiral lactones. Among screening-scale experiments, Candida pelliculosa ZP22 was selected as the most effective biocatalyst for the oxidation of monocyclic diols $\mathbf{3 a}-\mathbf{b}$ with respect to the ratio of high conversion to stereoselectivity. This strain was used in the preparative oxidation, affording enantiomerically-enriched isomers of lactones: $(+)-(3 \mathrm{a} R, 7 \mathrm{aS})$-cis-hexahydro- $1(3 \mathrm{H})$ -isobenzofuranone (2a) and (+)-(3aS,4,7,7aR)-cis-tetrahydro-1 $(3 \mathrm{H})$-isobenzofuranone (2b). Scaling up the culture growth, as well as biotransformation conditions has been successfully accomplished. Among more bulky substrates, bicyclic diol 3d was totally converted into enantiomerically-pure exo-bridged (+)-(3aR,4S,7R,7aS)-cis-tetrahydro-4,7methanoisobenzofuran -1(3H)-one (2d) by Yarrovia lipolytica AR71. Microbial oxidation of diol 3f by Candida sake AM908 and Rhodotorula rubra AM4 afforded optically-pure cis-3butylhexahydro-1 $(3 H)$-isobenzofuranone (2f), however with low conversion.
\end{abstract}

Keywords: biooxidation; yeast; lactones; diols; stereoselectivity; scaling up 


\section{Introduction}

The most dynamically-developing field of research on the border of chemistry and biology is biocatalysis, namely the application of microorganisms or isolated enzymes to carry out chemical transformations in a stereospecific way [1-6]. Biocatalysis allows stereochemical control of reactions and often provides chiral compounds. Biotransformations are characterized by high enantio-, regio- and chemo-selectivity. Moreover, reactions of low-reactive chemicals and reactions of non-activated areas of the molecule are possible. This usually leads to products that are very difficult to obtain by chemical synthesis. Biotransformation as an environmentally-friendly process requires mild conditions (temperature, $\mathrm{pH}$ ), decreases the consumption of chemicals and reduces side reactions and toxic chemical waste.

The application of isolated enzymes offers several benefits; however, the whole cell biocatalysis approach is typically used when a specific biotransformation requires multiple enzymes [7-9]. Whole cell catalysts can be much more readily prepared in comparison with isolated enzymes. Moreover, enzymes in cells are protected from the external environment, which makes them generally more stable in long-term storage than free enzymes. Bioxidation in the culture of whole cells of microorganisms seems to be a significant alternative method to the enzyme-mediated oxidation processes. From the economical point of view, the application of whole cells is a significantly more cost-effective method than using commercially-available enzymes, due to the much higher cost of enzymes, as well as expensive coenzymes.

Small-scale optimization of bioprocesses using a microtiter plate (MTP) has been of interest over the last few years [10-14]. Screening applications, such as media optimizations and looking for new microorganisms, require examination of a large number of cultures. For this purpose, shaken MTP, which provides high throughput at the minimal expense time, money and work effort, was developed [15-17]. Once screening is done, the development of a productive bioprocess is required. Therefore, scaling up the biotransformation from a microtiter plate to a laboratory bioreactor was the aim of this study.

Microbial stereoselective one-step conversion of diols affording enantiomerically-pure lactones is a definitively attractive approach [18-22]. Unfortunately, HLADH isolated from horse liver widely applied in the 1980s for chemoselective oxidation of meso diols is no longer available [23-26]. Since commercial oxidoreductases have not indicated complete stereoselectivity, there is a need to explore microorganisms in terms of looking for a novel alcohol dehydrogenase activity [20,27]. Based on our former screening tests, it has been shown that whole cells of bacteria effectively catalyze stereoselective oxidation of meso diols to the corresponding chiral lactones [19]. However, not all lactones were obtained in both optically-pure forms. Therefore, our efforts are currently directed toward employing whole cell cultures of different species of yeast in an extension of the biocatalysts' range in lactone biosynthesis. It is worth mentioning that whole cells of yeast are well known from the reduction of the $\mathrm{C}=\mathrm{O}[28-30]$ and $\mathrm{C}=\mathrm{C}$ [31-35] bonds, as well as the formation of the $\mathrm{C}=\mathrm{C}$ [36] bond and hydrolysis activity [37]. In general, reports on oxidation reactions performed by yeasts are quite rare $[38,39]$.

The inspiration for our research in this area is the fact that the development of the stereoselective microbial oxidation step is of high importance in the multi-step synthesis of optically-active lactones of a bicyclo[4.3.0]nonane structure. Such lactones, comprising a large group of phthalide derivatives, are isolated from plants of the family Apiaceae Lindl. They possess very attractive biological 
activities [40-42]. We are especially interested in the biosynthesis of enantiomerically-pure bicyclic lactones with selective growth inhibitory activities towards filamentous fungi of Aspergillus, Penicillium and Fusarium genera.

\section{Results and Discussion}

\subsection{Synthesis of Diols $\mathbf{3 a}-\boldsymbol{f}$ and Lactones $2 \boldsymbol{a}-\boldsymbol{f}$}

Meso diols 3a-e, the substrates in the biotransformations carried out, as well as racemic lactones 2a-e, the products of those biotransformations, were obtained from commercially available anhydrides 1a-d by the reduction method with lithium aluminum hydride (Scheme 1). Among synthesized substrates were monocyclic diols with a cyclohexane ring (3a) and the unsaturated analog (3b), as well as bicyclic diols with the structure of [2.2.1] (3c-d) and [2.2.2] (3e).

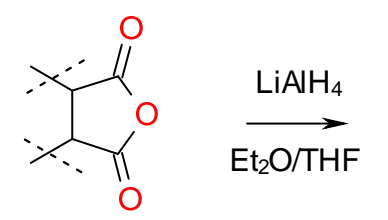

1a-e

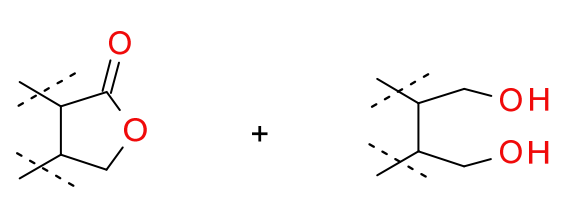

2a-e

3a-e a:<smiles>CC(C)=CCCC=CC(C)(C)C</smiles>

b:

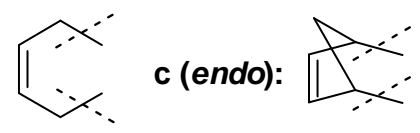

d (exo):<smiles>CC12C=CC(C1)C(C)(C)C2(C)C</smiles>

e:<smiles>CC1CC2CCC1C2(C)C</smiles>

Scheme 1. Reduction of anhydrides $1 \mathbf{a}-\mathbf{e}$ to corresponding racemic lactones $\mathbf{2 a}-\mathbf{e}$ and meso diols $\mathbf{3 a}-\mathbf{e}$.

The substrate for biotransformation, diol 3f, was synthesized by the reduction of corresponding lactone $\mathbf{2 f}$, which was previously obtained from anhydride 1a in a three-step synthesis described by us earlier [43] (Scheme 2).

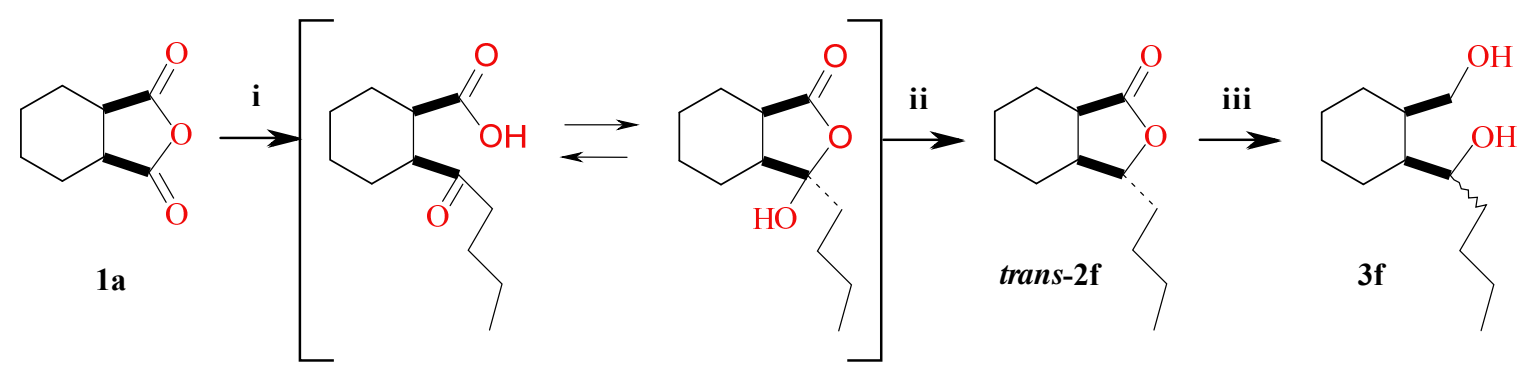

Scheme 2. Synthesis of phthalide lactone $2 \mathbf{f}$ and corresponding diol $\mathbf{3 f}$. (i) (1) $\mathrm{Cd}\left(n-\mathrm{C}_{4} \mathrm{H}_{9}\right)_{2}$, $\mathrm{Et}_{2} \mathrm{O}$ or $\mathrm{THF}$, (2) $\mathrm{HCl}$; (ii) (1) $\mathrm{NaBH}_{4}, \mathrm{MeOH}$, (2) $\mathrm{THF}: \mathrm{H}_{2} \mathrm{O}: \mathrm{HClO}_{4}$, reflux; (iii) (1) $\mathrm{LiAlH}_{4}, \mathrm{Et}_{2} \mathrm{O}$ or THF, (2) $\mathrm{HCl}$. 


\subsection{Screening Scale Biotransformations of Monocyclic Meso Diols $3 \boldsymbol{a}-\boldsymbol{b}$}

Based on our previous studies, it has been shown that whole cells of bacteria catalyze stereoselective oxidation of meso diols $\mathbf{3 a}-\mathbf{e}$ to the corresponding optically-active lactones $\mathbf{2 a}-\mathbf{e}$ [19]. However, we were especially interested in obtaining both enantiomers of lactones. Therefore, in extending the pool of biocatalysts of the oxidation process, we decided to examine some yeast strains for this purpose.

As a continuation of our research on scaling up the biotransformation methodology, we initially conducted experiments in microtiter plates. Then, the selected conditions were moved directly into a bioreactor. We decided to skip screening of the microbial transformations in shake flasks due to the observed repeatable results between MTPs and shake flasks. Microtiter plate-based screening platforms have lately become an attractive alternative to shake flasks, mainly because of cost- and labor-efficient cultivations for screening purposes and the ease of automation.

Screening bioxidation of 3a-b, conducted in an MTP platform, involved 29 strains of different genera of yeast (Scheme 3). Only a few of them, presented in Tables 1 and 2, were able to convert diols $\mathbf{3 a}-\mathbf{b}$ into the corresponding lactones $\mathbf{2} \mathbf{a}-\mathbf{b}$ with a conversion and enantioselectivity range from poor to very good, depending on the strain used.

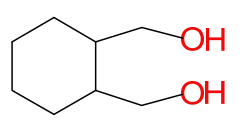

$3 a$

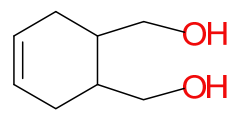

$3 \mathbf{b}$

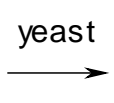

yeast

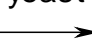

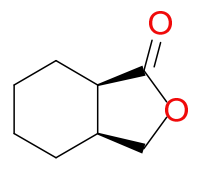

$(-)-(3 a S, 7 a R)-\mathbf{2 a}$

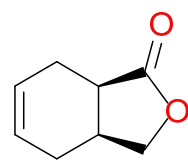

$(+)-(3 \mathrm{a}, 7 \mathrm{a} R)-\mathbf{2 b}$<smiles>O=C1OC[C@H]2CCCC[C@H]12</smiles>

$(+)-(3 \mathrm{a} R, 7 \mathrm{a} S)-\mathbf{2 a}$

or<smiles>O=C1OC[C@H]2CC=CC[C@H]12</smiles>

$(-)-(3 a R, 7 a S)-\mathbf{2 b}$

Scheme 3. Microbial oxidation of monocyclic meso diols 3a-b catalyzed by whole cells of yeast.

Table 1. The conversion (according to chiral gas chromatography, CGC) of diol 3a in the course of screening-scale oxidation conducted in a microtiter plate (MTP).

\begin{tabular}{ccccc}
\hline \multirow{2}{*}{ Strain } & \multirow{2}{*}{ Time (day) } & \multirow{2}{*}{ Conversion of Diol 3a (\%) } & \multicolumn{2}{c}{ Lactone 2a } \\
\cline { 4 - 6 } & & $\boldsymbol{e e}(\%)$ & Isomer \\
\hline Candida pelliculosa ZP22 & 14 & 92 & 70 & $(+)-(3 \mathrm{a} R, 7 \mathrm{a} S)$ \\
Candida viswanathi AM120 & 21 & 9 & 0 & racemic \\
Saccharomyces cerevisiae AM464 & 21 & 20 & 95 & $(+)-(3 \mathrm{a} R, 7 \mathrm{a} S)$ \\
Saccharomyces pastorianus 906 & 21 & $>99$ & 0 & racemic \\
Yarrowia lipolytica AR71 & 21 & 60 & 68 & $(+)-(3 \mathrm{a} R, 7 \mathrm{a} S)$ \\
Yarrowia lipolytica AR72 & 21 & 44 & 58 & $(+)-(3 \mathrm{a} R, 7 \mathrm{a} S)$ \\
Rhodotorula glutinis AM242 & 14 & 20 & 50 & $(-)-(3 \mathrm{a} S, 7 \mathrm{a} R)$ \\
Rhodotorula marina 77 & 21 & 12 & 10 & $(-)-(3 \mathrm{a} S, 7 \mathrm{a} R)$ \\
Rhodotorula rubra AM82 & 21 & 28 & 6 & $(-)-(3 \mathrm{a} S, 7 \mathrm{a} R)$ \\
Rhodotorula rubra AM4 & 21 & 18 & 10 & $(-)-(3 \mathrm{a} S, 7 \mathrm{a} R)$ \\
\hline
\end{tabular}


In the screening biooxidation of $\mathbf{3 a}$, ten strains were selected with potential dehydrogenase activity (Table 1). In the efficient transformation of $\mathbf{3 a}$ (conversion $=92 \%$ ) catalyzed by Candida pelliculosa ZP22, the enantiomerically-enriched isomer of $(+)-(3 \mathrm{a} R, 7 \mathrm{aS})$-lactone $\mathbf{2 a}$ (enantiomeric excess $(e e)=70 \%$ ) was obtained. The same stereoisomer of $\mathbf{2 a}$, but with a significantly lower conversion (20\%), was synthesized via biotransformation with Saccharomyces cerevisiae AM464. On the other hand, complete conversion ( $>99 \%$ ) of 3a took place in the oxidation with S. pastorianus 906; however, a racemic mixture of 2a was obtained. Both strains of Yarrowia lipolytica species (Y. lipolytica AR71, Y. lipolytica AR72) exhibited modest conversion (44\%-60\%) of 3a, as well as stereoselectivity (ee $=58 \%-68 \%$ ). All of the yeast from the genus Rhodotorula (R. glutinis AM242, R. marina AM77, R. rubra AM82, R. rubra AM4) showed opposite enantioselectivity toward other tested strains and the oxidized 3a to the (-)-(3aS,7aR)-isomer of $\mathbf{2 a}$, however with a significantly lower degree of conversion (12\%-28\%) and enantiomeric excesses $(e e=6 \%-50 \%)$, as well.

Screening transformations of $\mathbf{3 b}$ indicated that lactone $\mathbf{2} \mathbf{b}$ can be obtained only by three strains of yeast among all investigated (Table 2). It is interesting that in all cases, the complete conversion $(>99 \%)$ of $\mathbf{3 b}$ was observed, although with different optical purities. Likewise, in the oxidation of 3a, C. pelliculosa ZP22 afforded $(+)-(3 \mathrm{aS}, 7 \mathrm{aR})-\mathbf{2 b}$ with the highest enantiomeric excess $(e e=68 \%)$. The formation of the same isomer $(+)-(3 \mathrm{a} S, 7 \mathrm{a} R)-\mathbf{2 b}(\mathrm{ee}=50 \%)$ occurred also in $Y$. lipolytica AR71 culture. The opposite enantiomerically-enriched isomer $(-)-(3 \mathrm{a} R, 7 \mathrm{aS})-\mathbf{2} \mathbf{b}(e e=40 \%)$ was formed in the biotransformation catalyzed by S. cerevisiae AM464.

Table 2. The conversion (according to chiral gas chromatography, CGC) of diol $\mathbf{3 b}$ in the course of screening-scale oxidation conducted in MTP.

\begin{tabular}{ccccc}
\hline \multirow{2}{*}{ Strain } & \multirow{2}{*}{ Time (day) } & \multirow{2}{*}{ Conversion of Diol 3b (\%) } & \multicolumn{2}{c}{ Lactone 2b } \\
\cline { 4 - 6 } & & & $\boldsymbol{e e ~ ( \% )}$ & Isomer \\
\hline Candida pelliculosa ZP22 & 14 & $>99$ & 68 & $(+)-(3 \mathrm{a} S, 7 \mathrm{a} R)$ \\
\hline Saccharomyces cerevisiae AM464 & 21 & $>99$ & 40 & $(-)-(3 \mathrm{a} R, 7 \mathrm{a} S)$ \\
\hline Yarrowia lipolytica AR71 & 21 & $>99$ & 50 & $(+)-(3 \mathrm{a} S, 7 \mathrm{a} R)$ \\
\hline
\end{tabular}

It is worth mentioning the fact that C. pelliculosa ZP22 and Y. lipolytica AR71 catalyzed the formation of the $(+)-(3 \mathrm{a} S, 7 \mathrm{a} R)$-isomer of $\mathbf{2} \mathbf{b}$. Based on our previous studies, all of the tested bacteria produced the opposite isomer $(-)-(3 \mathrm{a} R, 7 \mathrm{a} S)-\mathbf{2 b}$ [19]. Moreover, as we proved earlier, commercially available native horse liver alcohol dehydrogenase (HLADH), as well as HLADH recombinant in Escherichia coli catalyzed the oxidation of $\mathbf{3 b}$ to the opposite isomer (-)-(3aR,7aS)-2b [27].

Among screening-scale experiments of the oxidation of diols $\mathbf{3 a}-\mathbf{b}$, C. pelliculosa ZP22 was the most effective yeast strain for lactone synthesis with respect to the ratio of high conversion to stereoselectivity. It is worth pointing out that the aforementioned strain, described for the first time by Felcenloben and Piegza, was isolated from hardly degradable petroleum waste [44]. Besides the high lipase activity of $C$. pelliculosa ZP22 determined by the authors, the dehydrogenase activity discovered by us makes this strain much more interesting.

On the basis of the preliminary studies, C. pelliculosa ZP22 and other two strains, Y. lipolytica AR71 and S. cerevisiae AM464, were selected and applied for further optimization of the oxidation of 3a-b. Screening experiments focused on conducting biotransformation in different $\mathrm{pHs}$ of medium 
(acidic, neutral and basic; Table 3). Neither Y. lipolytica AR71 nor S. cerevisiae AM464 improved the stereoselectivity of biotransformation. C. pelliculosa ZP22, independent of the $\mathrm{pH}$ environment, catalyzed the oxidation of $\mathbf{3 a}-\mathbf{b}$ the most effectively. As it turned out, the $\mathrm{pH}$ of the medium did not have any significant effect on the microbial oxidation.

Table 3. The conversion (according to chiral gas chromatography, CGC) of diols $\mathbf{3 a}-\mathbf{b}$ in the course of screening-scale oxidation in different $\mathrm{pHs}$ of the medium conducted in MTP.

\begin{tabular}{|c|c|c|c|c|c|c|c|c|c|c|c|c|c|}
\hline \multirow{3}{*}{ Strain } & \multirow{3}{*}{$\begin{array}{l}\text { Time } \\
\text { day } \\
\end{array}$} & \multicolumn{6}{|c|}{ Lactone 2a } & \multicolumn{6}{|c|}{ Lactone $2 b$} \\
\hline & & \multicolumn{2}{|c|}{ pH 4.5} & \multicolumn{2}{|c|}{ pH 7.2} & \multicolumn{2}{|c|}{ pH 8.5} & \multicolumn{2}{|c|}{ pH 4.5} & \multicolumn{2}{|c|}{ pH 7.2} & \multicolumn{2}{|c|}{ pH 8.5} \\
\hline & & $(\%)$ & $e e(\%)$ & $(\%)$ & $e e(\%)$ & $(\%)$ & $e e(\%)$ & $(\%)$ & $e e(\%)$ & $(\%)$ & $e e(\%)$ & $(\%)$ & $e e(\%)$ \\
\hline $\begin{array}{c}\text { Candida } \\
\text { pelliculosa ZP22 }\end{array}$ & 14 & $>99$ & 68 & $>99$ & 66 & 95 & 64 & $>99$ & 64 & $>99$ & 68 & $>99$ & 70 \\
\hline $\begin{array}{c}\text { Saccharomyces } \\
\text { cerevisiae } \\
\text { AM464 }\end{array}$ & 21 & 0 & - & 0 & - & 0 & - & $>99$ & 54 & $>99$ & 24 & $>99$ & 50 \\
\hline $\begin{array}{c}\text { Yarrowia } \\
\text { lipolytica } \\
\text { AR71 }\end{array}$ & 21 & 89 & 58 & 94 & 58 & 94 & 56 & 59 & 50 & 60 & 50 & 52 & 50 \\
\hline
\end{tabular}

Further conditions' optimization concerned selection of the optimal medium for growth and biotransformation of 3a-b by C. pelliculosa ZP22 (see the Experimental Section). It is known that different carbon and nitrogen sources, as well as the addition of mineral salts and vitamins has a significant influence on biocatalyst metabolism. Among seven different media (A, C, E, G, M, P, S, for media composition see Experimental section 3.5) applied, microbial oxidation of $\mathbf{3 a}-\mathbf{b}$ was the most effective in the corresponding $\mathrm{P}$ and $\mathrm{A}$ medium due to the shortest time of biotransformation and the highest enantiomeric excesses of lactones $\mathbf{2 a - b}$ formed. Therefore, both media were selected for preparative oxidation experiments conducted in a bioreactor.

\subsection{Preparative-Scale Biotransformations of Monocyclic Meso Diols $3 \mathbf{a}-\boldsymbol{b}$}

One of the aims of this study was to improve a scale up methodology from a microtiter plate up to a bioreactor. C. pelliculosa ZP22 was selected as the most effective biocatalyst from the screening of the secondary metabolite biosynthesis performed in MTP. This strain was used in a preparative oxidation in a bench-scale reactor.

During the processes performed in the bioreactor, few parameters were under control, among them the $\mathrm{pH}$ of the culture medium. The growth of $C$. pelliculosa $\mathrm{ZP} 22$ was carried out in $\mathrm{pH}=6.3-6.7$, since the logarithmic growth phase $(\mathrm{pH}=3.9-4.3)$ had been reached. Biotransformation was finished when the culture medium reached $\mathrm{pH}=8.6$. Our observations showed the increase of the $\mathrm{pH}$ during the whole microbial process.

After seven days of microbial oxidation conducted in Sabouraud medium (P), optically-active $(+)-(3 \mathrm{a} R, 7 \mathrm{a} S)-2 \mathrm{a}$ with $e e=72 \%$ was formed. This result was consistent with the screening biotransformation of 3a in MTP. Therefore, it verified the rational approach for the down-stream 
process from MTP directly to the bioreactor. Microbial oxidation of $\mathbf{3 b}$ performed in enriched medium (A) afforded enantiomerically-enriched $(+)-(3 \mathrm{aS}, 7 \mathrm{aR})-\mathbf{2 b}(e e=50 \%)$.

\subsection{Screening-Scale Biotransformations of Bicyclic Meso Diols 3c-e}

The results obtained from biotransformations of monocyclic diols $\mathbf{3 a}-\mathbf{b}$, encourage us to test other substrates, bicyclic diols $\mathbf{3 c}-\mathbf{e}$, which differed in the structure (ring size) and stereochemistry (exo- and endo-) (Scheme 4). Screening experiments were set up with all available yeast strains in microtiter plates, allowing for a rapid screening of $\mathbf{3 c}-\mathbf{e}$.

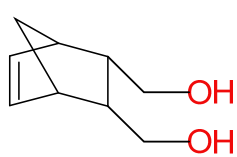

3c

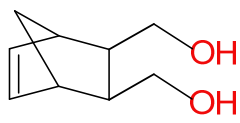

3d

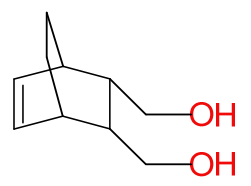

$3 e$

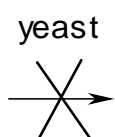

yeast

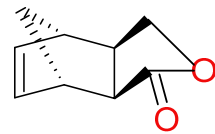

$(+)-(3 \mathrm{a} R, 4 S, 7 R, 7 \mathrm{a} S)-\mathbf{2 d}$

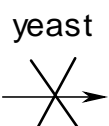

Scheme 4. Microbial oxidation of bicyclic meso diols $3 \mathbf{c}-\mathbf{e}$ catalyzed by whole cells of yeast.

More bulky substrates, bicyclic diols $\mathbf{3 c}-\mathbf{e}$, were not as effectively oxidized by yeast as monocyclic diols 3a-b. Among the diols 3c-e tested, only 3d was converted into the (+)-exo-bridged isomer of lactone $\mathbf{2 d}$ by the selected strains (Table 4 ). The most stereoselective biotransformation was catalyzed by $Y$. lipolytica AR71, affording the $(+)-(3 \mathrm{a} R, 4 S, 7 R, 7 \mathrm{a} S)$-enantiomer of $\mathbf{2 d}$ with complete conversion of $\mathbf{3 d}$. Other microorganisms able to conduct biooxidation of $\mathbf{3 d}$ were also identified, however with considerably lower conversion or enantiomeric excess. It is worth mentioning that the spatial structure of the substrate played a significant role in the stereoselectivity of biotransformation; thus, the endo-bridged isomer of lactone $\mathbf{2 c}$ was not formed. None of tested yeast transformed diol with the structure of [2.2.2] (3e) to the corresponding lactone $\mathbf{2 e}$, either.

The results obtained from the oxidation of bicyclic diols $\mathbf{3 c}-\mathbf{e}$ involving whole cells of yeast in comparison with bacteria indicated significantly higher bacterial dehydrogenase activity [19]. In the case of the formation of lactone $\mathbf{2 d}$ in the culture of $Y$. lipolytica AR71, the same $(+)-(3 \mathrm{a} R, 4 S, 7 R, 7 \mathrm{a} S)$-isomer as in all transformations catalyzed by bacteria was identified. Taking into account the high cost of corresponding anhydride 1d in comparison to other anhydrides $1 \mathbf{a}-\mathbf{c}$ and $1 \mathbf{e}$ and the same stereoselectivity of biotransformations catalyzed by bacteria, we did not perform transformations of $\mathbf{3 d}$ in a preparative scale. 
Table 4. The conversion (according to chiral gas chromatography, CGC) after 14 days of diol 3d in the course of screening-scale oxidation conducted in MTP.

\begin{tabular}{cccc}
\hline \multirow{2}{*}{ Strain } & \multirow{2}{*}{ Conversion of Diol 3d (\%) } & \multicolumn{2}{c}{ Lactone 2d } \\
\cline { 3 - 4 } & & $\boldsymbol{e e ~ ( \% )}$ & Isomer \\
\hline Candida viswanathi AM120 & $>99$ & 64 & $(+)-(3 \mathrm{a} R, 4 S, 7 R, 7 \mathrm{a} S)$ \\
\hline Saccharomyces pastorianus 906 & $>99$ & 50 & $(+)-(3 \mathrm{a} R, 4 S, 7 R, 7 \mathrm{a} S)$ \\
\hline Yarrowia lipolytica AR71 & $>99$ & $>99$ & $(+)-(3 \mathrm{a} R, 4 S, 7 R, 7 \mathrm{a} S)$ \\
\hline Rhodotorula glutinis AM242 & $>99$ & 54 & $(+)-(3 \mathrm{a} R, 4 S, 7 R, 7 \mathrm{a} S)$ \\
\hline Rhodotorula rubra AM82 & 15 & 80 & $(+)-(3 \mathrm{a} R, 4 S, 7 R, 7 \mathrm{a} S)$ \\
\hline Rhodotorula rubra AM4 & 15 & 76 & $(+)-(3 \mathrm{a} R, 4 S, 7 R, 7 \mathrm{a} S)$ \\
\hline
\end{tabular}

\subsection{Screening Scale Biotransformations of Diol $3 f$}

As we mentioned earlier, our interests are focused on the biosynthesis of phthalide lactone derivatives. Encouraged by good results from the transformations of meso monocyclic diols $\mathbf{3 a}-\mathbf{b}$, we checked the possibility of the oxidation of diol $\mathbf{3 f}$ with primary and secondary hydroxyl groups by yeast. A mixture of diastereoisomers of lactone $\mathbf{2 f}$ were the products of biooxidation that were possible to obtain (Scheme 5). However, the preliminary screening studies showed that all of the biocatalysts transformed $\mathbf{3 f}$ to the cis-isomer of lactone $\mathbf{2 f}$ with different enantiomeric excess (Table 5).

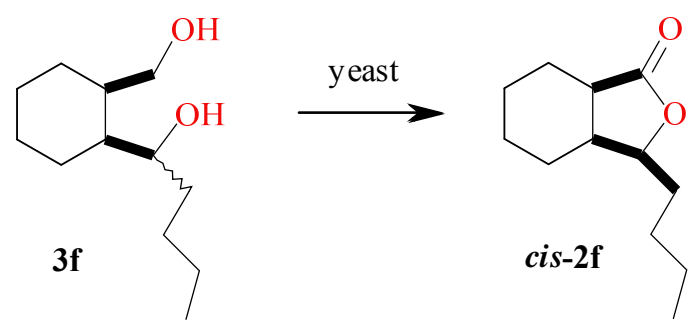

Scheme 5. Microbial oxidation of diol $3 f$ to lactone cis-2f catalyzed by whole cells of yeast.

Table 5. The conversion (according to chiral gas chromatography, CGC) after 21 days of diol $\mathbf{3 f}$ in the course of screening-scale oxidation conducted in MTP.

\begin{tabular}{ccc}
\hline Strain & Conversion of Diol 3f (\%) & Lactone 2f ee (\%) \\
\hline Candida viswanathi AM120 & 11 & 21 \\
\hline Candida sake AM908 & 18 & $>99$ \\
\hline Candida parapsilosis AM909 & 22 & 38 \\
\hline Yarrowia lipolytica AR71 & 4 & 62 \\
\hline Rhodotorula marina 77 & 9 & 21 \\
\hline Rhodotorula rubra AM82 & 11 & 98 \\
\hline Rhodotorula rubra AM4 & 17 & $>99$ \\
\hline
\end{tabular}

A highly stereoselective biotransformation was mainly catalyzed by yeast of the Candida and Rhodotorula genera. It is noteworthy that C. pelliculosa ZP22, which was the most efficient biocatalyst in the oxidation of meso diols $\mathbf{3 a}-\mathbf{b}$, did not transform $\mathbf{3 f}$ at all. Apparently, this strain possesses 
dehydrogenases responsible only for primary hydroxy group oxidation or the butyl chain in substrate $\mathbf{3 f}$ causes steric hindrance, preventing enzymatic oxidation.

Unfortunately, the conversion of $\mathbf{3 f}$ did not exceed $22 \%$; therefore, the biotransformation on the preparative scale was not performed, and the absolute configuration of the cis-isomer of $\mathbf{2} \mathbf{f}$, formed predominately, was not determined. Such low conversion of $\mathbf{3 f}$ requires further looking for efficient biocatalysts for the oxidation process. Besides whole cells of yeast, in the near future, we are going to apply filamentous fungi and bacteria in the microbial oxidation of different phthalide derivatives diols. Till now, the more efficient biosynthetic approach to obtain optically-active phthalide lactone $\mathbf{2 f}$ seems to be a microbial one-pot oxidation of meso diol 3a at first. The second step involves starting from enantiomerically-enriched lactone $(+)-\mathbf{2 a}$, the chemically-introduced butyl chain following the procedure described in the literature [45] (Scheme 6).

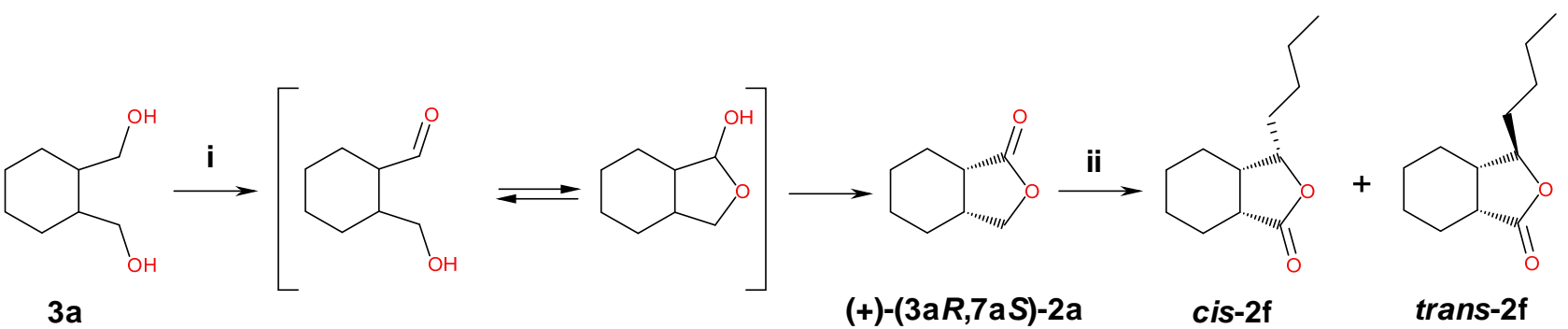

Scheme 6. Stereoselective synthesis of optically-active phthalide lactones $2 \mathrm{f}$. (i) yeast; (ii) (1) $n-\mathrm{C}_{4} \mathrm{H}_{9} \mathrm{MgBr}$ (2 equiv.), $\mathrm{Zn}\left(\mathrm{BH}_{4}\right)_{2}$ (0.25 equiv.), THF, rt, (2) $\mathrm{HCl}_{\mathrm{aq}}$, (3) TPAP (cat.), $\mathrm{NMO}, \mathrm{CH}_{2} \mathrm{Cl}_{2}, 4{ }^{\circ} \mathrm{C}$

\section{Experimental Section}

\subsection{Analysis}

Compounds' purity was checked by thin layer chromatography on silica gel (DC-Alufolien Kieselgel 60 F254, Merck) with methylene chloride:methanol (95:5) as an eluent. Compounds were detected by spraying the plates with $1 \% \mathrm{Ce}\left(\mathrm{SO}_{4}\right)_{2}, 2 \% \mathrm{H}_{3}\left[\mathrm{P}\left(\mathrm{Mo}_{3} \mathrm{O}_{10}\right)_{4}\right]$ in $10 \% \mathrm{H}_{2} \mathrm{SO}_{4}$, followed by heating to $120^{\circ} \mathrm{C}$. Preparative column chromatography $\left(\mathrm{SiO}_{2}\right.$, Kieselgel 60, 230-400 mesh, 40-63 $\mu \mathrm{m}$, Merck) was performed with the application of methylene chloride:methanol (95:5) or hexane:acetone (3:1) as an eluent. Gas chromatography analysis (GC, FID, carrier gas $\mathrm{H}_{2}$ ) was carried out on Agilent Technologies 7890N (GC System, Santa Clara, CA, USA) with the HP-5 column (cross-linked methyl silicone, $30 \mathrm{~m} \times 0.32 \mathrm{~mm} \times 0.25 \mu \mathrm{m}$, Santa Clara, CA, USA). Enantiomeric excesses of the products were determined on chiral columns: Cyclosil-B $(30 \mathrm{~m} \times 0.25 \mathrm{~mm} \times 0.25 \mu \mathrm{m}$, Santa Clara, CA, USA) for lactones 2a, 2b, 2c, 2e, 2f and Astec Chiral-DEX B-PM (30 m $\times 0.25 \mathrm{~mm} \times 0.12 \mu \mathrm{m}$, St. Louis, MO, USA) for lactone 2d. ${ }^{1} \mathrm{H}$ NMR and ${ }^{13} \mathrm{C}$ NMR spectra were recorded in $\mathrm{CDCl}_{3}$ solution on a Bruker Avance $^{\mathrm{TM}} 600$ (600 MHz, Billerica, MA, USA) spectrometer. IR spectra were determined on a FT-IR Thermo-Nicolet IR300 (Waltham, Ma, USA) infrared spectrometer. Optical rotations were measured on an Autopol IV automatic polarimeter (Rudolph, Hackettstown, NJ, USA) in chloroform solutions, concentrations denoted in $\mathrm{g} / 100 \mathrm{~mL}$. 


\subsection{Chemicals}

cis-4-Cyclohexene-1,2-dicarboxylic anhydride (1b), cis-5-norbornene-endo-2,3-dicarboxylic anhydride (1c), cis-5-norbornene-exo-2,3-dicarboxylic anhydride (1d), endo-bicyclo[2.2.2]oct-5-ene-2,3-dicarboxylic anhydride (1e) and $\mathrm{LiAlH}_{4}$ were purchased from Sigma-Aldrich Chemical Co., St. Louis, MO, USA, while cis-cyclohexane-1,2-dicarboxylic anhydride (1a) was purchased from Fluka BioChemika.

\subsection{Synthesis of Meso Diols $3 \boldsymbol{a}-\boldsymbol{e}$ and Lactones $2 \boldsymbol{a}-\boldsymbol{e}$}

A solution of anhydride 1a-e $(6 \mathrm{mmol})$ in a mixture of diethyl ether $(20 \mathrm{~mL})$ and tetrahydrofuran $(10 \mathrm{~mL})$ was added dropwise to $\mathrm{LiAlH}_{4}(8 \mathrm{mmol})$ in diethyl ether $(20 \mathrm{~mL})$. The mixture was stirred for $16 \mathrm{~h}$ under reflux. When the reaction was completed (controlled by gas chromatography (GC), thin layer chromatography (TLC)), water was added to decompose the excess of $\mathrm{LiAlH}_{4}$. The mixture was then acidified with $0.1 \mathrm{M} \mathrm{HCl}$, and the products were extracted with chloroform. Then, the extract was washed with saturated $\mathrm{NaCl}$ and dried over anhydrous $\mathrm{MgSO}_{4}$. The crude products were purified by column chromatography (silica gel, methylene chloride:methanol (95:5). The spectral data of diols 3a-e were presented earlier [19]. The yields and spectral data of lactones $\mathbf{2 a - e}$ are given below.

\subsection{1. cis-Hexahydro-1(3H)-isobenzofuranone ( $( \pm)-(\mathbf{2 a})$}

Yield 28.6\%, ${ }^{1} \mathrm{H}$ NMR (500 MHz, $\left.\mathrm{CDCl}_{3}\right) \delta: 0.80-0.98\left(\mathrm{~m}, 1 \mathrm{H}\right.$, one of $\left.\mathrm{CH}_{2}-4\right), 1.05-1.30(\mathrm{~m}, 5 \mathrm{H}$, $\mathrm{CH}_{2}-6, \mathrm{CH}_{2}-5$, one of $\left.\mathrm{CH}_{2}-4\right), 1.34\left(\mathrm{~d}, 1 \mathrm{H}, \mathrm{J}=10.2 \mathrm{~Hz}\right.$, one of $\left.\mathrm{CH}_{2}-7\right), 1.45-1.95\left(\mathrm{~m}, 1 \mathrm{H}\right.$, one of $\left.\mathrm{CH}_{2}-7\right)$, $2.10(\mathrm{dd}, 1 \mathrm{H}, J=23.3,11.0 \mathrm{~Hz}, \mathrm{H}-7 \mathrm{a}), 2.35-2.70$ (m, 1H, H-3a), $3.92\left(\mathrm{~d}, 1 \mathrm{H}, J=8.8 \mathrm{~Hz}\right.$, one of $\left.\mathrm{CH}_{2}-3\right)$, $4.16\left(\mathrm{dd}, 1 \mathrm{H}, J=8.8,5.0 \mathrm{~Hz}\right.$, one of $\left.\mathrm{CH}_{2}-3\right)$; ${ }^{13} \mathrm{C} \mathrm{NMR}\left(151 \mathrm{MHz}, \mathrm{CDCl}_{3}\right) \delta: 22.4\left(\mathrm{CH}_{2}-4\right), 22.8$ $\left(\mathrm{CH}_{2}-6\right), 23.3\left(\mathrm{CH}_{2}-5\right), 27.1\left(\mathrm{CH}_{2}-7\right), 35.3(\mathrm{CH}-3 \mathrm{a}), 39.4(\mathrm{CH}-7 \mathrm{a}), 71.7\left(\mathrm{CH}_{2}-3\right), 178.6(\mathrm{C}=\mathrm{O})$; IR (film, $\left.\mathrm{cm}^{-1}\right)$ : $1766(\mathrm{~s})$; GC-EIMS: $140(\mathrm{M}+1)$.

\subsection{2. cis-3a,4,7,7a-Tetrahydro-1(3H)-isobenzofuranone $( \pm)-(\mathbf{2 b})$}

Yield 7.5\%, ${ }^{1} \mathrm{H}$ NMR (500 MHz, $\left.\mathrm{CDCl}_{3}\right) \delta$ : 1.77-2.05 (m, 1H, one of $\left.\mathrm{CH}_{2}-4\right), 1.90-2.90(\mathrm{~m}, 3 \mathrm{H}$, one of $\mathrm{CH}_{2}-4, \mathrm{H}-3 \mathrm{a}$, one of $\left.\mathrm{CH}_{2}-7\right), 2.74-2.80\left(\mathrm{~m}, 2 \mathrm{H}\right.$, one of $\left.\mathrm{CH}_{2}-7, \mathrm{H}-7 \mathrm{a}\right), 4.00(\mathrm{dd}, 1 \mathrm{H}, \mathrm{J}=8.8,2.0$ $\mathrm{Hz}$, one of $\left.\mathrm{CH}_{2}-3\right), 4.30\left(\mathrm{dd}, 1 \mathrm{H}, J=8.8,5.1 \mathrm{~Hz}, 1 \mathrm{H}\right.$, one of $\left.\mathrm{CH}_{2}-3\right), 5.60-5.70(\mathrm{~m}, 2 \mathrm{H}, \mathrm{H}-6, \mathrm{H}-5)$; ${ }^{13} \mathrm{C}$ NMR (151 MHz, $\left.\mathrm{CDCl}_{3}\right)$ 8: $21.9\left(\mathrm{CH}_{2}-4\right), 24.6\left(\mathrm{CH}_{2}-7\right), 31.9(\mathrm{CH}-7 \mathrm{a}), 37.2(\mathrm{CH}-3 \mathrm{a}), 72.7\left(\mathrm{CH}_{2}-3\right)$, 124.8 (CH-5), 125.1 (CH-6), $179.1(\mathrm{C}=\mathrm{O})$; IR (film, $\left.\mathrm{cm}^{-1}\right)$ : 1771 (s); GC-EIMS: $138(\mathrm{M}+1)$.

\subsection{3. cis-endo-3a,4,7,7a-Tetrahydro-4,7-methanoisobenzofuran-1(3H)-one $( \pm)-(\mathbf{2 c})$}

Yield 25.5\%, ${ }^{1} \mathrm{H}$ NMR $\left(500 \mathrm{MHz} \mathrm{CDCl}_{3}\right) \delta: 1.44\left(\mathrm{~d}, J=8.7 \mathrm{~Hz}, 1 \mathrm{H}\right.$, one of $\left.\mathrm{CH}_{2}-8\right), 1.62(\mathrm{td}, J=8.6$, $1.5 \mathrm{~Hz}, 1 \mathrm{H}$, one of $\left.\mathrm{CH}_{2}-8\right), 3.07(\mathrm{~m}, 1 \mathrm{H}, \mathrm{CH}-4), 3.09(\mathrm{~m}, 1 \mathrm{H}, \mathrm{CH}-3 \mathrm{a}), 3.22(\mathrm{dd}, J=9.3,4.7 \mathrm{~Hz}, 1 \mathrm{H}$, CH-7a), 3.31 (m, 1H, CH-7), $3.77\left(\mathrm{dd}, J=9.7,3.1 \mathrm{~Hz}, 1 \mathrm{H}\right.$ one of $\left.\mathrm{CH}_{2}-3\right), 4.26(\mathrm{t}, J=8.6 \mathrm{~Hz}, 1 \mathrm{H}$, one of $\left.\mathrm{CH}_{2}-3\right), 6.23-6.31$ (m, 2H, CH-5, CH-6); $\left.{ }^{13} \mathrm{C} \mathrm{NMR} \mathrm{(151} \mathrm{MHz,} \mathrm{CDCl}_{3}\right) \delta: 40.3\left(\mathrm{CH}_{2}-3 \mathrm{a}\right), 45.8(\mathrm{CH}-4)$, 46.1 (CH-7), 47.6 (CH-7a), 51.8 (CH-8), $70.3\left(\mathrm{CH}_{2}-3\right), 134.4(\mathrm{CH}-5), 136.9(\mathrm{CH}-6), 178.0(\mathrm{C}=\mathrm{O})$; IR (film, $\left.\mathrm{cm}^{-1}\right): 1758(\mathrm{~m})$; GC-EIMS: $150(\mathrm{M}+1)$. 
3.3.4. cis-exo-3a,4,7,7a-Tetrahydro-4,7-methanoisobenzofuran-1(3H)-one $( \pm)-(\mathbf{2 d})$

Yield 16.5\%, ${ }^{1} \mathrm{H}$ NMR $\left(500 \mathrm{MHz}, \mathrm{CDCl}_{3}\right) \delta: 1.46\left(\mathrm{~d}, J=9.7 \mathrm{~Hz}, 1 \mathrm{H}\right.$, one of $\left.\mathrm{CH}_{2}-8\right), 1.54(\mathrm{td}, J=7.7$, $1.6 \mathrm{~Hz}, 1 \mathrm{H}$, one of $\left.\mathrm{CH}_{2}-8\right), 2.54(\mathrm{t}, J=8.3 \mathrm{~Hz}, 1 \mathrm{H}, \mathrm{CH}-3 \mathrm{a}), 2.63(\mathrm{~d}, J=8.5 \mathrm{~Hz}, 1 \mathrm{H}, \mathrm{CH}-7 \mathrm{a}), 2.88$ (m, $1 \mathrm{H}, \mathrm{CH}-4), 3.26(\mathrm{~m}, 1 \mathrm{H}, \mathrm{CH}-7), 3.97$ (dd, $J=9.8,3.5 \mathrm{~Hz}, 1 \mathrm{H}$, one of $\left.\mathrm{CH}_{2}-3\right), 4.46(\mathrm{t}, J=9.1,1 \mathrm{H}$, one of $\left.\mathrm{CH}_{2}-3\right), 6.15-6.24$ (m, 2H, CH-5, CH-6); $\left.{ }^{13} \mathrm{C} \mathrm{NMR} \mathrm{(151} \mathrm{MHz,} \mathrm{CDCl}_{3}\right) \delta: 41.9(\mathrm{CH}-3 \mathrm{a}), 43.3\left(\mathrm{CH}_{2}-8\right)$, 46.4 (CH-7), 47.9 (CH-7a), 48.2 (CH-4), $71.9\left(\mathrm{CH}_{2}-3\right), 137.6(\mathrm{CH}-5), 137.7(\mathrm{CH}-6), 177.7(\mathrm{C}=\mathrm{O})$; IR (film, $\left.\mathrm{cm}^{-1}\right): 1756(\mathrm{~m})$; GC-EIMS: $150(\mathrm{M}+1)$.

\subsection{5. cis-endo-3a,4,7,7a-Tetrahydro-4,7-ethanoisobenzofuran-1(3H)-one $( \pm)-(\mathbf{2 e})$}

Yield 3.8\%, ${ }^{1} \mathrm{H}$ NMR (500 MHz, $\left.\mathrm{CDCl}_{3}\right) \delta: 1.09-1.36\left(\mathrm{~m}, 2 \mathrm{H}, \mathrm{CH}_{2}-9\right), 1.38-1.64\left(\mathrm{~m}, 2 \mathrm{H}, \mathrm{CH}_{2}-8\right)$, 2.67 (m, 2H, CH-7, CH-4), 2.74 (dd, $J=10.2,3.2 \mathrm{~Hz}, 1 \mathrm{H}, \mathrm{CH}-3 \mathrm{a}), 3.06$ (m, 1H, CH-7a), 3.82 (dd, $J=9.3,3.9 \mathrm{~Hz}, 1 \mathrm{H}$, one of $\left.\mathrm{CH}_{2}-3\right), 4.32\left(\mathrm{t}, J=8.9 \mathrm{~Hz}, 1 \mathrm{H}\right.$, one of $\left.\mathrm{CH}_{2}-3\right), 6.23-6.34(\mathrm{~m}, 2 \mathrm{H}, \mathrm{CH}-5$,

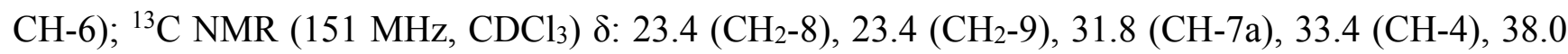
(CH-7), 44.8 (CH-3a), $72.4\left(\mathrm{CH}_{2}-3\right), 132.6$ (CH-5), 134.3 (CH-6), 179.3 (C=O); IR (film, cm $\left.{ }^{-1}\right): 1757$ (m); GC-EIMS: $164(\mathrm{M}+1)$.

\subsection{Synthesis of Diol $3 f$ and Lactone $2 f$}

1-(2-(Hydroxymethyl)cyclohexyl)pentan-1-ol (3f) was synthesized by the reduction of corresponding trans-3-butylhexahydro-1(3H)-isobenzofuranone (2f), which was previously obtained from cis-cyclohexane-1,2-dicarboxylic anhydride (1a) in a three-step synthesis described by us earlier [43]. The yields and spectral data of diol $\mathbf{3 f}$ and lactone $\mathbf{2} \mathbf{f}$ are given below.

\subsubsection{1-(2-(Hydroxymethyl)cyclohexyl)pentan-1-ol ( $( \pm)-(\mathbf{3 f})$}

Yield 50\%, ${ }^{1} \mathrm{H}$ NMR (600 MHz, $\left.\mathrm{CDCl}_{3}\right) \delta: 0.91\left(\mathrm{t}, 3 \mathrm{H}, J=7.1 \mathrm{~Hz}, \mathrm{CH}_{3}-14\right), 1.17-1.26$ (m, 1H, one of $\left.\mathrm{CH}_{2}-5\right), 1.26-1.38\left(\mathrm{~m}, 3 \mathrm{H}, \mathrm{CH}_{2}-13\right.$, one of $\left.\mathrm{CH}_{2}-3\right), 1.38-1.52\left(\mathrm{~m}, 8 \mathrm{H}, \mathrm{CH}_{2}-11, \mathrm{CH}_{2}-6\right.$, one of $\mathrm{CH}_{2}-5, \mathrm{CH}_{2}-4$, one of $\left.\mathrm{CH}_{2}-3\right), 1.52-1.63(\mathrm{~m}, 1 \mathrm{H}, \mathrm{CH}-1), 1.63-1.75$ (m, 2H, $\left.\mathrm{CH}_{2}-12\right), 2.12-2.22$ (m, $1 \mathrm{H}, \mathrm{CH}-2), 2.71(\mathrm{~s}, 2 \mathrm{H}, 2 \mathrm{xOH}), 3.51$ (dd, $1 \mathrm{H}, \mathrm{J}=10.9,3.1 \mathrm{~Hz}$, one of $\left.\mathrm{CH}_{2}-9\right), 3.53-3.59$ (m, 1H, CH-7), $3.95\left(\mathrm{t}, 1 \mathrm{H}, J=10 \mathrm{~Hz}\right.$, one of $\left.\mathrm{CH}_{2}-9\right)$; ${ }^{13} \mathrm{C} \mathrm{NMR}\left(151 \mathrm{MHz}, \mathrm{CDCl}_{3}\right) \delta: 14.1\left(\mathrm{CH}_{3}-14\right), 22.5\left(\mathrm{CH}_{2}-4\right)$, $22.8\left(\mathrm{CH}_{2}-13\right), 25.8\left(\mathrm{CH}_{2}-12\right), 25.9\left(\mathrm{CH}_{2}-5\right), 28.1\left(\mathrm{CH}_{2}-3\right), 30.3\left(\mathrm{CH}_{2}-6\right), 34.5\left(\mathrm{CH}_{2}-11\right), 37.3(\mathrm{CH}-2)$, 44.7 (CH-1), $63.4\left(\mathrm{CH}_{2}-9\right), 74.0(\mathrm{CH}-7)$.

\subsection{2. trans-3-Butylhexahydro-1(3H)-isobenzofuranone ( \pm )-(2f)}

Yield 45\%, ${ }^{1} \mathrm{H}$ NMR (500 MHz, $\left.\mathrm{CDCl}_{3}\right), \delta: 0.85$ (t, 3H, $\left.J=7.1 \mathrm{~Hz}, \mathrm{CH}_{3}-11\right), 1.28-1.39$ (m, 3H, one of $\left.\mathrm{CH}_{2}-9, \mathrm{CH}_{2}-10\right), 1.45-1.50\left(\mathrm{~m}, 1 \mathrm{H}\right.$, one of $\left.\mathrm{CH}_{2}-9\right), 1.50-1.54\left(\mathrm{~m}, 1 \mathrm{H}\right.$, one of $\left.\mathrm{CH}_{2}-8\right), 1.68-1.74$ (m, $1 \mathrm{H}$, one of $\left.\mathrm{CH}_{2}-8\right), 1.77-1.82\left(\mathrm{~m}, 1 \mathrm{H}\right.$, one of $\left.\mathrm{CH}_{2}-4\right), 1.94-1.97\left(\mathrm{~m}, 1 \mathrm{H}\right.$, one of $\left.\mathrm{CH}_{2}-4\right), 2.30-2.32$ (m, 1H, one of $\left.\mathrm{CH}_{2}-7\right), 2.38-2.41\left(\mathrm{~m}, 1 \mathrm{H}\right.$, one of $\left.\mathrm{CH}_{2}-7\right), 2.49-2.51(\mathrm{~m}, 1 \mathrm{H}, \mathrm{CH}-3 \mathrm{a}), 2.78-2.81$ (m, 1H, CH-7a), 4.29-4.32 (m, 1H, CH-3), 5.63-5.65 (m, 2H, CH-5, CH-6); ${ }^{13} \mathrm{C}$ NMR (151 MHz), $\delta: 13.9$ $\left(\mathrm{CH}_{3}-11\right), 19.6\left(\mathrm{CH}_{2}-10\right), 22.0\left(\mathrm{CH}_{2}-4\right), 22.6\left(\mathrm{CH}_{2}-7\right), 28.0(\mathrm{CH}-7 \mathrm{a}), 28.9\left(\mathrm{CH}_{2}-9\right), 35.3\left(\mathrm{CH}_{2}-8\right), 40.0$ 
(CH-3a), 82.6 (CH-3), 124.4 (CH-5), 125.2 (CH-6), 178.7 (C=O); IR (NaCl, cm $\left.{ }^{-1}\right)$ : 3019 (s), 2400 (m), 1767 (s), 1521 (m); GC-EIMS: $195(\mathrm{M}+1)$.

\subsection{Growth Conditions}

The compositions of the culture media $\left(\mathrm{g} / 1 \mathrm{~L} \mathrm{H}_{2} \mathrm{O}\right)$ are as follows:

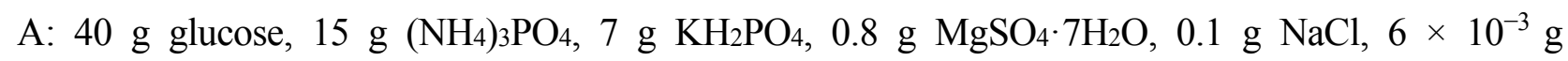
$\mathrm{ZnSO}_{4} \cdot 7 \mathrm{H}_{2} \mathrm{O}, 5 \times 10^{-3} \mathrm{~g} \mathrm{CuSO}_{4} \cdot 5 \mathrm{H}_{2} \mathrm{O}, 1 \times 10^{-3} \mathrm{~g} \mathrm{MnSO}_{4} \cdot 4 \mathrm{H}_{2} \mathrm{O}$;

C: $30 \mathrm{~g}$ saccharose, $3 \mathrm{~g} \mathrm{NaNO}_{3}, 1 \mathrm{~g} \mathrm{KH}_{2} \mathrm{PO}_{4}, 0.5 \mathrm{~g} \mathrm{MgSO}_{4} \cdot 7 \mathrm{H}_{2} \mathrm{O}, 0.5 \mathrm{~g} \mathrm{KCl}, 0.01 \mathrm{~g} \mathrm{FeSO}_{4}$;

E: $10 \mathrm{~g}$ starch, $4 \mathrm{~g}$ yeast extract, $0.1 \mathrm{~g} \mathrm{~K}_{2} \mathrm{HPO}_{4}, 0.05 \mathrm{~g} \mathrm{MgSO} \cdot 7 \mathrm{H}_{2} \mathrm{O}$;

$\mathrm{G}: 10 \mathrm{~g}$ glucose, $0.5 \mathrm{~g}$ asparagine, $0.5 \mathrm{~g} \mathrm{~K}_{2} \mathrm{HPO}_{4}$;

$\mathrm{M}$ : $40 \mathrm{~g}$ glucose, $2 \mathrm{~g}$ asparagine, $0.5 \mathrm{~g}$ thiamine, $0.5 \mathrm{~g} \mathrm{KH}_{2} \mathrm{PO}_{4}, 0.25 \mathrm{~g} \mathrm{MgSO}_{4} \cdot 7 \mathrm{H}_{2} \mathrm{O}$;

$\mathrm{P:} 30 \mathrm{~g}$ glucose, $10 \mathrm{~g}$ peptone;

S: $10 \mathrm{~g}$ glucose, $2.5 \times 10^{-3}$ g genistein, $2.5 \mathrm{~g} \mathrm{~K}_{2} \mathrm{HPO}_{4}, 2.5 \mathrm{~g} \mathrm{NaNO}_{3}$.

\subsection{Microorganisms}

The following yeast strains were used for screening: Rhodotorula marina AM77, Rhodotorula glutinis AM242, Rhodotorula rubra AM4, Rhodotorula rubra AM82, Rhodotorula mucilaginosa IHEM18459, Yarrowia lipolytica AM71, Yarrowia lipolytica AM72, Yarrowia lipolytica 0302, Saccharomyces cerevisiae AM464, Saccharomyces cerevisiae FY1679, Saccharomyces cerevisiae MG2180, Saccharomyces cerevisiae 1278bKANR, Saccharomyces cerevisiae BY4741, Saccharomyces cerevisiae LI303, Saccharomyces brasiliensis AM905, Saccharomyces pastorianus AM906, Saccharomyces carlsbergensis, Zygosaccharomyces bailii AM907, Sporobolomyces 0202, Sporobolomyces 0203, Candida sake AM908, Candida parapsilosis AM909, Candida viswanathi AM120, Candida pelliculosa ZP22, Candida albicans 2214, Candida albicans ATCC90028, Candida parapsilosis IHEM3270, Candida glabrata 66, Candida glabrata 2046.

The microorganisms came from the Department of Chemistry and the Department of Biotechnology and Food Microbiology at Wroclaw University of Environmental and Life Sciences (Poland); the Institute of Biology and Botany Medical University (Wroclaw, Poland); the Department of Special Analyses of the Researches and Teaching Institute for Brewing (VLB, Berlin); the Department of Biological Sciences at Wroclaw University. They were maintained at $4{ }^{\circ} \mathrm{C}$ on Sabouraud agar slants containing peptone $(10 \mathrm{~g})$, glucose $(40 \mathrm{~g})$ and agar $(15 \mathrm{~g})$ dissolved in water $(1 \mathrm{~L})$ at $\mathrm{pH} 5.5$.

\subsection{Biotransformations of Diols $3 \boldsymbol{a}-\boldsymbol{f}$}

\subsubsection{Screening-Scale Biotransformations in Microtiter Plates}

An overnight precultured yeast strain $(0.1 \mathrm{~mL})$ was added to each well of MTP containing $4 \mathrm{~mL}$ of different media (A, C, E, G, M, P, S) and incubated at $25{ }^{\circ} \mathrm{C}$ on a rotary shaker $(180 \mathrm{rpm}$, shaking diameter $50 \mathrm{~mm}$ ) [15-17]. After 2 days of cultivation, a $5 \mathrm{mM}$ solution of $\mathbf{3 a}-\mathbf{f}$ in $0.05 \mathrm{~mL}$ of acetone was added to the grown cultures. Two milliliter samples were taken from the reaction mixture after 7, 14, 21 days to estimate the progress of the biotransformation. Samples were acidified by $0.1 \mathrm{M} \cdot \mathrm{HCl}(0.01 \mathrm{~mL})$, 
washed with brine $(0.01 \mathrm{~mL})$ and extracted with ethyl acetate $(1 \mathrm{~mL})$ for 20 mins on a vortexer (600 rpm, shaking diameter $4.5 \mathrm{~mm})$. After extraction, MTP was balanced and centrifuged $(10,000$ rpm, 5 mins). Finally, the organic phase from each well of MTP was transferred to a GC vial and analyzed on a $\mathrm{GC}$ instrument equipped with an autosampler.

In control experiments, the diols $\mathbf{3 a}-\mathbf{e}$ were incubated in sterile growth medium without microorganism to check substrate stability. Additionally, a control culture containing medium was inoculated by microorganisms to estimate the metabolites formed by biocatalyst.

\subsubsection{Preparative-Scale Biotransformation in a Bioreactor}

Preparative biotransformations were carried out in a 7-L bioreactor (Brunswick, Ramsey, MN, USA) in the optimized conditions established on the basis of screening experiments. The parameters, medium volume $(3.0 \mathrm{~L})$, aeration rate $(1 \mathrm{v} / \mathrm{m})$, stirring speed $(600 \mathrm{rpm})$, temperature $\left(23{ }^{\circ} \mathrm{C}\right), \mathrm{pH}(3.9-8.6)$, were under control. The progress of the biotransformation was followed by gas chromatography. The reaction mixture was extracted overnight according to the procedure described in the screening scale. The crude product was purified by column chromatography using a mixture of hexane/acetone (3:1) as a mobile phase. The yields of the biotransformation and enantiomeric excess with optical rotation of the lactones obtained are given below.

\subsubsection{Preparative Oxidation of Meso Diols 3a-b Catalyzed by Candida pelliculosa ZP22}

Oxidation of 3a $(0.7 \mathrm{~g})$ after 7 days gave $0.29 \mathrm{~g}(42 \%$ yield $)$ of $(+)-(3 \mathrm{a} R, 7 \mathrm{aS})-\mathbf{2 a}$, ee $=72 \%$ $\left([\alpha]_{589}^{25}=+36.5^{\circ}\left(\mathrm{c}=2.2, \mathrm{CHCl}_{3}\right)\right.$, ref. [23] $\left.[\alpha]_{589}^{25}=+48.8^{\circ}\left(\mathrm{c}=0.5, \mathrm{CHCl}_{3}\right), e e=100 \%\right)$.

Oxidation of $\mathbf{3 b}(0.85 \mathrm{~g})$ after 11 days gave $0.43 \mathrm{~g}(50 \%$ yield $)$ of $(+)-(3 \mathrm{aS}, 7 \mathrm{a} R)-\mathbf{2 b}, e e=50 \%$ $\left([\alpha]_{589}^{25}=+48.4^{\circ}\left(\mathrm{c}=1.0, \mathrm{CHCl}_{3}\right)\right.$, ref. [23] $\left.[\alpha]_{589}^{25}=-67.1^{\circ}\left(\mathrm{c}=1.0, \mathrm{CHCl}_{3}\right), e e=100 \%\right)$.

\section{Conclusions}

Microbial stereoselective one-step conversion of meso diols is a convenient rout to obtain chiral lactones. Screening among yeast afforded a potential candidate, C. pelliculosa ZP22, with attractive alcohol dehydrogenase activity. Enantiomerically-enriched isomers of lactones $(+)-(3 \mathrm{a} R, 7 \mathrm{a} S)-\mathbf{2 a}$ and $(+)-(3 \mathrm{aS}, 7 \mathrm{a} R)-\mathbf{2} \mathbf{b}$ were obtained in the efficient biotransformations of corresponding diols $\mathbf{3} \mathbf{a}-\mathbf{b}$ in a preparative scale. Based on our previous studies, whole cells of bacteria and commercially available enzymes, involving HLADH, catalyzed the oxidation of $\mathbf{3 b}$ to the opposite isomer (-)-(3aR,7aS)-2 $\mathbf{b}$. An initially performed microbial cultivation based on a 24 -well plate format was moved successfully to the semi-preparative scale conducted in the bioreactor. Among more bulky substrates, only $\mathbf{3 d}$ was totally converted into the exo-bridged $(+)-(3 \mathrm{a} R, 4 S, 7 R, 7 \mathrm{a} S)$-enantiomer of lactone $\mathbf{2 d}$ by $Y$. lipolytica AR71. Microbial oxidation of $\mathbf{3 f}$ by Candida sake AM908 and Rhodotorula rubra AM4 afforded the enantiomerically-pure cis-isomer of lactone $\mathbf{2 f}$, however with low conversion.

\section{Acknowledgments}

This work was financed by the National Science Centre, Grant No. 2011/03/B/NZ9/05005. Publication supported by Wroclaw Centre of Biotechnology, programme The Leading National 
Research Centre (KNOW) for years 2014-2018 (http://know.wroc.pl). We would like to thank Enriqueta Martinez-Rojas from the University of Applied Sciences Neubrandenburg, as well as Ewa Obłąk from Wroclaw University for delivering yeast strains. We thank also Isaura Felcenloben and Michał Piegza from Wroclaw University of Environmental and Life Sciences for delivering Candida pelliculosa ZP22. We would also like to show our gratitude to the students, Natalia Włodarska and Karolina Anna Lisowska, from Students Scientific Association OrgChem, who contributed to the research.

\section{Author Contributions}

F.B. and T.O. conceived of and designed the experiments. F.B. E.S. and J.P. performed the experiments. F.B. analyzed the data. F.B. wrote the paper.

\section{Conflicts of Interest}

The authors declare no conflict of interest.

\section{References}

1. Breuer, M.; Ditrich, K.; Habicher, T.; Hauer, B.; Keßeler, M.; Stürmer, R.; Zelinski, T. Industrial methods for the production of optically active intermediates. Angew. Chem. Int. Ed. 2004, 43, 788-824.

2. Muñoz Solano, D.; Hoyos, P.; Hernáiz, M.J.; Alcántara, A.R.; Sánchez-Montero, J.M. Industrial biotransformations in the synthesis of building blocks leading to enantiopure drugs. Bioresour. Technol. 2012, 115, 196-207.

3. Nestl, B.M.; Nebel, B.A.; Hauer, B. Recent progress in industrial biocatalysis. Curr. Opin. Chem. Biol. 2011, 15, 187-193.

4. Brenna, E.; Fuganti, C.; Gatti, F.G.; Serra, S. Biocatalytic methods for the synthesis of enantioenriched odor active compounds. Chem. Rev. 2011, 111, 4036-4072.

5. Muschiol, J.; Peters, C.; Oberleitner, N.; Mihovilovic, M.D.; Bornscheuer, U.T.; Rudroff, F. Cascade catalysis-Strategies and challenges en route to preparative synthetic biology. Chem. Commun. 2015, 51, 5798-5811.

6. Lopez-Gallego, F.; Schmidt-Dannert, C. Multi-enzymatic synthesis. Curr. Opin. Chem. Biol. 2010, 14, 174-183.

7. Deasy, R.E.; O’Riordan, N.; Maguire, A.R. Baker's yeast mediated reduction of 2-acetyl-3-methyl sulfolane. Catalysts 2014, 4, 186-195.

8. Nakamura, K.; Yamanaka, R.; Matsuda, T.; Harada, T. Recent developments in asymmetric reduction of ketones with biocatalysis. Tetrahedron Asymmetr. 2003, 14, 2659-2681.

9. Brenna, E.; Dei Negri, C.; Fuganti, C.; Serra, S. Baker's yeast-mediated approach to (-)-cis- and (+)-trans-aerangis lactones. Tetrahedron Asymmetr. 2001, 12, 1871-1879.

10. Sohoni, S.; Bapat, P.; Lantz, A. Robust, small-scale cultivation platform for Streptomyces coelicolor. Microb. Cell Fact. 2012, 11, 1-10.

11. Wen, Y.; Zang, R.; Zhang, X.; Yang, S.-T. A 24-microwell plate with improved mixing and scalable performance for high throughput cell cultures. Process Biochem. 2012, 47, 612-618. 
12. Chen, A.; Chitta, R.; Chang, D.; Amanullah, A. Twenty-four well plate miniature bioreactor system as a scale-down model for cell culture process development. Biotechnol. Bioeng. 2009, 102, 148-160.

13. Betts, J.; Baganz, F. Miniature bioreactors: Current practices and future opportunities. Microb. Cell Fact. 2006, doi:10.1186/1475-2859-5-21.

14. Forchin, M.C.; Crotti, M.; Gatti, F.G.; Parmeggiani, F.; Brenna, E.; Monti, D. A rapid and high-throughput assay for the estimation of conversions of ene-reductase-catalysed reactions. ChemBioChem 2015, 16, 1571-1573.

15. Duetz, W. Microtiter plates as mini-bioreactors: Miniaturization of fermentation methods. Trends Microbiol. 2007, 15, 469-475.

16. Duetz, W.; Witholt, B. Oxygen transfer by orbital shaking of square vessels and deepwell microtiter plates of various dimensions. Biochem. Eng. J. 2004, 17, 181-185.

17. Duetz, W.A.; Rüedi, L.; Hermann, R.; O’Connor, K.; Büchs, J.; Witholt, B. Methods for intense aeration, growth, storage, and replication of bacterial strains in microtiter plates. Appl. Environ. Microb. 2000, 66, 2641-2646.

18. Boratyński, F.; Kiełbowicz, G.; Wawrzeńczyk, C. Lactones 34 [1]. Application of alcohol dehydrogenase from horse liver (HLADH) in enantioselective synthesis of $\delta$ - and $\varepsilon$-lactones. J. Mol. Catal. B 2010, 65, 30-36.

19. Boratyński, F.; Pannek, J.; Walczak, P.; Janik-Polanowicz, A.; Huszcza, E.; Szczepańska, E.; Martinez-Rojas, E.; Olejniczak, T. Microbial alcohol dehydrogenase screening for enantiopure lactone synthesis: Down-stream process from microtiter plate to bench bioreactor. Process Biochem. 2014, 49, 1637-1646.

20. Boratyński, F.; Smuga, M.; Wawrzeńczyk, C. Lactones 42. Stereoselective enzymatic/microbial synthesis of optically active isomers of whisky lactone. Food Chem. 2013, 141, 419-427.

21. Moreno-Horn, M.; Martinez-Rojas, E.; Görisch, H.; Tressl, R.; Garbe, L.A. Oxidation of 1,4-alkanediols into g-lactones via g-lactols using Rhodococcus erythropolis as biocatalyst. J. Mol. Catal. B 2007, 49, 24-27.

22. Romano, A.; Gandolfi, R.; Nitti, P.; Rollini, M.; Molinari, F. Acetic acid bacteria as enantioselective biocatalysts. J. Mol. Catal. B 2002, 17, 235-240.

23. Jakovac, I.J.; Goodbrand, H.B.; Lok, K.P.; Jones, J.B. Enzymes in organic synthesis. 24. Preparations of enantiomerically pure chiral lactones via stereospecific horse liver alcohol dehydrogenase catalyzed oxidations of monocyclic meso diols. J. Am. Chem. Soc. 1982, 104, 4659-4665.

24. Lok, K.P.; Jakovac, I.J.; Jones, J.B. Enzymes in organic synthesis. 34. Preparations of enantiomerically pure exo- and endo-bridged bicyclic [2.2.1] and [2.2.2] chiral lactones via stereospecific horse liver alcohol dehydrogenase catalyzed oxidations of meso diols. J. Am. Chem. Soc. 1985, 107, 2521-2526.

25. Bridges, A.J.; Raman, P.S.; Ng, G.S.Y.; Jones, J.B. Enzymes in organic synthesis. 31. Preparations of enantiomerically pure bicyclic [3.2.1] and [3.3.1] chiral lactones via stereospecific horse liver alcohol dehydrogenase catalyzed oxidations of meso diols. J. Am. Chem. Soc. 1984, 106, 1461-1467.

26. Jones, J.B.; Francis, C.J. Enzymes in organic synthesis. 32. Stereospecyfic horse liver alcohol dehydrogenase-Catalyzed oxidations of exo- and endo-oxabicyclic meso diols. Can. J. Chem. 1984, 62, 2578-2582. 
27. Olejniczak, T.; Boratyński, F.; Białońska, A. Fungistatic activity of bicycle [4.3.0]-g-lactones J. Agric. Food Chem. 2011, 59, 6071-6081.

28. Soni, P.; Banerjee, U.C. Biotransformations for the production of the chiral drug (S)-duloxetine catalyzed by a novel isolate of Candida tropicalis. Appl. Microbiol. Biotechnol. 2005, 67, 771-777.

29. Matsuyama, A.; Yamamoto, H.; Kawada, N.; Kobayashi, Y. Industrial production of (R)-1,3butanediol by new biocatalysts. J. Mol. Catal. B 2001, 11, 513-521.

30. Dehli, J.R.; Gotor, V. Dynamic kinetic resolution of 2-oxocycloalkanecarbonitriles: Chemoenzymatic syntheses of optically active cyclic $\beta$ - and $\gamma$-amino alcohols. J. Org. Chem. 2002, 67, 6816-6819.

31. Stuermer, R.; Hauer, B.; Hall, M.; Faber, K. Asymmetric bioreduction of activated C $=\mathrm{C}$ bonds using enoate reductases from the old yellow enzyme family. Curr. Opin. Chem. Biol. 2007, 11, 203-213.

32. Kawai, Y.; Inaba, Y.; Tokitoh, N. Asymmetric reduction of nitroalkenes with baker's yeast. Tetrahedron Asymmetr. 2001, 12, 309-318.

33. Serra, S.; Fuganti, C.; Gatti, F.G. A chemoenzymatic, preparative synthesis of the isomeric forms of $p$-menth-1-en-9-ol: Application to the synthesis of the isomeric forms of the cooling agent 1-hydroxy-2,9-cineole. Eur. J. Org. Chem. 2008, 1031-1037.

34. Fronza, G.; Fuganti, C.; Serra, S. Stereochemical course of baker's yeast mediated reduction of the tri- and tetrasubstituted double bonds of substituted cinnamaldehydes. Eur. J. Org. Chem. 2009, 2009, 6160-6171.

35. Sortino, M.A.; Filho, V.C.; Zacchino, S.A. Highly enantioselective reduction of the C-C double bond of $\mathrm{N}$-phenyl-2-methyl- and $\mathrm{N}$-phenyl-2,3-dimethyl-maleimides by fungal strains. Tetrahedron Asymmetr. 2009, 20, 1106-1108.

36. Csuk, R.; Glaenzer, B.I. Baker's yeast mediated transformations in organic chemistry. Chem. Rev. 1991, 91, 49-97.

37. Glänzer, B.I.; Faber, K.; Griengl, H. Microbial resolution of o-acetylpantoyl lactone. Enzyme Microb. Technol. 1988, 10, 689-690.

38. Patel, R.N.; Hou, C.T.; Laskin, A.I.; Derelanko, P.; Felix, A. Oxidation of secondary alcohols to methyl ketones by yeasts. Appl. Environ. Microb. 1979, 38, 219-223.

39. Nestl, B.; Voss, C.; Bodlenner, A.; Ellmer-Schaumberger, U.; Kroutil, W.; Faber, K. Biocatalytic racemization of sec-alcohols and $\alpha$-hydroxyketones using lyophilized microbial cells. Appl. Microb. Biotechnol. 2007, 76, 1001-1008.

40. Momin, R.A.; Nair, M.G. Mosquitocidal, nematicidal, and antifungal compounds from Apium graveolens L. seeds. J. Agric. Food Chem. 2001, 49, 142-145.

41. Beck, J.J.; Chou, S.-C. The structural diversity of phthalides from the Apiaceae. J. Nat. Prod. 2007, 70, 891-900.

42. Bartschat, D.; Beck, T.; Mosandl, A. Stereoisomeric flavor compounds. 79. Simultaneous enantioselective analysis of 3-butylphthalide and 3-butylhexahydro-phthalide stereoisomers in celery, celeriac, and fennel. J. Agric. Food Chem. 1997, 45, 4554-4557.

43. Walczak, P.; Pannek, J.; Boratyński, F.; Janik-Polanowicz, A.; Olejniczak, T. Synthesis and fungistatic activity of bicyclic lactones and lactams against Botrytis cinerea, Penicillium citrinum and Aspergillus glaucus. J. Agric. Food Chem. 2014, 62, 8571-8578. 
44. Zaleska, I.; Piegza, M. Asymilacja nietypowych źródeł węgla przez mikroorganizmy o specyficznych uzdolnieniach do życia w wysoko stresogennych środowiskach. Acta Sci. Pol. Biotechnol. 2008, 7, $27-43$.

45. Le Guillou, R.; Fache, F.; Piva, O. Reductive alkylation of anhydrides and lactones: Direct access to monosubstituted lactones. C. R. Chim. 2002, 5, 571-575.

(C) 2015 by the authors; licensee MDPI, Basel, Switzerland. This article is an open access article distributed under the terms and conditions of the Creative Commons Attribution license (http://creativecommons.org/licenses/by/4.0/). 